\title{
Multicultural Inevitability: Case of Georgia
}

\author{
Vladimir Liparteliani \\ Adam Mickiewicz University, Poznan, Poland
}

\begin{abstract}
The paper seeks to analyze the larger concept of multiculturalism and to further determine its role and importance in modern Georgia. The agenda of cultural diversity is often subject to criticism, accused for being responsible for endangering modern societies. Such statements will be critically analyzed within the context of the increasing farright sentiments among Georgians, as reflected in a what can be described as a radical march which took place in Tbilisi on the 14th of July 2017, creating risks of further deteriorating of the situation in the country, given the general macro-economic instability of Georgia and undermining democracy. This paper concludes that it is very important to establish an innovative new model of Georgian citizenship, and one which will address all the accumulated misunderstandings now existing in society. It is expected that this will enable multiculturalism to be perceived more appropriately, i.e. as a unifying ideology rather than a dividing force.
\end{abstract}

(c) (1) CC BY: Creative Commons Attribution License 4.0

\section{Introduction}

This paper concludes that it is very important to establish an innovative new model of Georgian citizenship, and one which will address all the accumulated misunderstandings now existing in society. It is expected that this will enable multiculturalism to be perceived more appropriately, i.e. as a unifying ideology rather than a dividing force.

\section{Understanding Multiculturalism}

Multiculturalism is often perceived as a modern invention by its detractors, and also, even more outrageously, equated with the genocide of national identities and states VESPA (2016). Such a negative image is also actively promoted by rightist movements in the West and by those who interpret liberal-democracy as the tool of some "Global Conspiracy" in which multiculturalism is an inseparable part of an "enslavement process" (Solargeneral.org, n.d).

Opponents treat assimilation as an essential part of multiculturalism and consider it as a threat for a mainstream culture. In this steam of reasoning, assimilation eliminates cultural differences though loss of one's distinctive traits that are replaced by the language, values, and other attributes, thus threatening dominant culture's exclusiveness. However, it will be necessary to return to these theories later and discuss them in more details. There are consequences facing those in Georgia who criticize multiculturalism as an ideology and among the same who often hold more or less the same opinions, and are guided by similar arguments. But for now we will begin investigating multiculturalism in Georgia by finding a better approach to understanding it.

When we first hear of something, most of us try to recall whether we heard anything about it before, and if so, what exactly links us to it. We will use the same approach to figure out what multiculturalism is. To start with, we will review multiculturalism in its historical context. This implies ignoring its ideological aspect and addressing its historical reality and role in different societies.

Multiculturalism is indisputably an actuality of world history, having been an indispensable part of cultural contacts from the earliest known civilization, that of the Sumerians of the fourth millennium B.C. “...what made the land of Sumer so critical was that it was where long-range trade routes over land and sea first came together... always and everywhere, civilizations involved polyethnic mingling, and attracted people who came from a distance to live, temporarily or permanently, in relatively close proximity... today this phenomenon is only intensified by the enormous capacity of modem transport and communication" (Foreign Policy Research Institute, 1999). Cultures in general, and particularly modern ones, are so multicultural and intertwined that even if you wanted to, it would be almost impossible to find strict differences between them.

That of Georgia is no exception. Today's globalized way of life excludes any doubts concerning the multicultural vector of development for any country. Furthermore, we can demonstrate multiculturalism's historical role by looking at the composition of Georgia's peoples, which have always been very diverse. "Historically, Georgia (like most other countries) has almost never been mono-ethnic. This was primarily predetermined by its geographical location"(Topchishvili, 2005).

Topchishvili stresses that nation does not pertain to natural but rather is a socio-cultural phenomenon. One that is continually developing, living organism, which over centuries absorbs the features and characteristics of different peoples. Every nation undergoes a long process of development, and, of course, always changes its form.

There is no nation in the world which has not emerged from interrelations with others. We are unlikely to find any nation with a pure bloodline and untapped culture, and even if such an entity exists somewhere it will not have the status of a nation, merely a tribe (Topchishvili, 2005). 
The idea of tolerance itself is not something new and fits well in historical format of traditions and cultures of different peoples. Georgia and the whole Caucasus region, being one of the most polyethnic regions in the world, is a great example in this context. Due to its geographic location Georgia has always been a point of contact for different civilizations and distinct with ethnocultural diversity throughout history. Culture of tolerance has been formed by influence from neighbors, invaders and trade partners of the country enriching it with new borrowings but at the same time allowing Georgians to keep their distinctiveness. Located at the crossroads of different parts of the world and serving as a bridge for fundamentally different cultures and philosophies of the north and south, east and west, Georgia, combining it all, is itself unique and self-sufficient.

Already in ancient periods, between 3rd and 7th C.E. Iberia (Georgian Kingdom of Kartli 302 BC-580 AD) maintained dangerous existence between two great powers of that time, Persia and The Byzantine Empire - rivals for control over the Caucasus. Georgian kings in order to preserve freedom had to play one off against the other. Such attempts at «balancing the scales» of course had an impact on cultural and religious spheres, building rich sociopolitical, cultural and demographic mosaic. There even were times of dual faith in Georgia, when Mazdaism (Zoroastrianism) had been accepted by eastern part of the country as a second official religion alongside with Christianity by the middle of the 5th century.

«Araboba» is also worth to be mentioned - the period of Arab rulers's domination in Georgia, continuing from 7th century until the final defeat of the Emirate of Tbilisi from King David IV in 1122, or devastating invasion of Mongols in the Caucasus and creation Vilayet of Gurjistan until the Turco-Mongol onslaught ruled by Temur in the last quarter of the 14th century. Particular attention in this case deserves settlement of more than 200000 Kipchaks in 1118-1120 years with a purpose of protection the country's borders and their future assimilation (Japaridze et al., 2012).

All these events could not pass without leaving impact on society, culture and religion of Georgians. Being a stage of constant wars between Persian and Osman Empires in the late middle ages dividing the country on the western and eastern parts, no surprise that Georgians, being Christians but strongly influenced by muslim neighbors, absorbed diverse features creating very specific own culture. Constantly changing situations on the borders, emergence and vanishing of new cultures in the region and migration have always been reality for the country rather than exception, contributing to what we consider to be Georgian culture today. Georgia's diverse composition is a great example of the universal multicultural past, present and probably future. The treasure of world literature called "The Knight in the Panther's Skin," by Shota Rustaveli, is undeniably a product of Georgian culture and is a prime conveyor of Georgian identity. But it could hardly have been created were it not for the multicultural reality of the Kingdom of Georgia of that time.

Information we get from Joseph Pitton de Tournefort, perfectly describes naturalness of multiculturalism for Georgia of the beginning of the 18th century : «There are five Greek Churches in Teflis, four in the city, and one in the suburb; seven Armenian Churches, two Mosques in the Citadel, and a third which is deserted...there are approximately 20.000 inhabitants in Tiflis. 14.000 of them are Armenians, 3.000 muslims, 2.000 Georgians and 500 Roman-Catholics». These lines from handbook of the traveler depict how diverse the capital was in ethnic, religious and cultural sense for that period. Not for nothing, the popular saying coming from Georgian peasants exists: "We are all children of Adam,// Tatar is also our brother,//Between us and Armenians,//What is the difference?" Topchishvili (2019a) Exactly due to such a diverse history many question whether to consider Georgia as a part of Europe or Asia in cultural aspect. Intelectuals still find the question to be contentious. While Europeans view Georgia as Asia, the last one sees it as Europe.

Very close relations with the northern neighbor, Russia, from the end of 18th century and its strong impact on Georgia until the moment should be mentioned in a bit more detailed way. Not only in the period of being a part of Russian Empire Georgia was influenced in different aspects, treating the Empire as the replacement of the long-lost Orthodox ally, the Eastern Roman Empire, but later in the Soviet Period the level of Russia's impact achieved its peak due to technologies as well as political and economic ties. The term «sovetskiy chelovek» was applicable to all citizens of the USSR including Georgians and consequences of that identity we see even now. The soviet identity played role of an institutional background in which identities of titular and non-titular ethnicities were forming. The soviet identity did not mean an ethnical sense, it rather was a civic identity. However at the same time it was still including some ethnic characteristics, for example being a soviet citizen meant being able to speak Russian language and know Russian culture as it served as a communicative instrument between different people. The situation with coexistence of ethnicities and cultures together was worsen by the concept of a titular nation. Representatives of different ethnic groups simply could not understand on what basis one group of people could be given a status of titular and others in spite of any attempts would never achieve this status. This all rose a level of ethnic complaints among people living side by side in the same republics. In spite of attempt to create multicultural society and unite different cultures and peoples together, the wrong approach and ideology did not allow the country to succeed in this. The authorities used to manage peaceful coexistence of nations mostly relying on power and undemocratic decisions. As the result, during the process of «de-sovetisation» many conflicts raised on the ethnical ground. Due to strong attachment of the soviet identity, «sovetchina», to Russian national identity, a deep alienation towards it appeared. All Russian became associated with all imperialistic and soviet and was strongly opposed Barbashin (2012). The tendency is the case at present.

Significant moment in the history of multiculturalism in Georgia, as well as, all post soviet states was acceptation of new liberal constitutions in 90s. Finally rights of ethnic minorities were legally protected and theoretically no any barrier could exist for prosperity of multiculturalism in the states. However, deepening in the problems and looking at the facts we are certain that theory and practice are too far from each other in this sense. 
Georgia's diverse composition is a great example of the universal multicultural past, present and probably future. The treasure of world literature called "The Knight in the Panther's Skin," by Shota Rustaveli, is undeniably a product of Georgian culture and a prime conveyor of Georgian identity. But it could hardly have been created were it not for the multicultural reality of the Kingdom of Georgia of that time.

It is difficult to argue that our modern reality has developed totally due to multiculturalism, because innovation may, amongst other things, also be provoked by the discrepancy between insiders and outsiders. Cultures have a very ambivalent attitude towards newcomers who, with their own cultures (folk ways), are usually perceived as a challenge to established system of values, traditions and rituals. But at the same time, however, it is important to understand that in any society, over time, innovation appears which later partly disappears and partly will become a tradition over time. Thus, any current tradition once was an innovation and some of current innovations once will become a tradition (Topchishvili, 2019b).

If a country's internal security is put under threat the members of this culture may see strangers as threatening, thinking, and "We have to protect our identity more and learn how to deal with strangers". But in such situations changes are inescapable, because even attempts to resist change lead to change, and thus intercultural contact becomes a source of innovation. This has been so for centuries, if not the whole history of humanity, and there are myriad examples.

Hence multiculturalism is a historical necessity, inevitability and is an essential part of humanity's progress. Even societies' fear of multiculturalism (often caused by unawareness) leads towards changes and innovations which prove that nation and culture are not static but dynamic and continually developing phenomena in which multiculturalism plays a key role. So what stops people perceiving this as a matter of course? Today, in the era of globalization, which is inherently global political, economic, religious and cultural integration and unification, due to the simplification of movement around the world, and thanks to opened borders of almost all countries, the development of technologies, and in particular of the Internet, people got the opportunity to acquaint people from other countries with their own and original cultures. Multiculturalism acquires global tendency and becomes essential part of globalized reality. Countries refusing to accept the reality are doomed to be isolated from the developed world. The importance of multiculturalism has been growing throughout the human history in step with increasing level of globalization.

\section{Criticism of Multiculturalism}

For the last few decades in the West, the strategy of the assimilation of newcomers, thus the regulation of intercultural and interethnic relations, has been changed by the adoption of the concept of cultural pluralism, i.e. multiculturalism. It should be noted that in this situation we are faced with the ideology of multiculturalism rather than its historical role. The main feature of this concept is tolerance of other cultures and ethno cultural identities. But in the same ratio that as multiculturalism has become ingrained in European societies, criticism of it has unfolded. The main argument against it is that this policy does not resolve disagreements between hosts and newcomers, but on the contrary increases contrasts and leads to social and cultural conflicts. The argument is based on the idea that encouraging minorities to express their distinct identities and practices creates the social exclusion of these minorities, whereas the proper approach would be to assimilate these minorities and ensure their Europeanization.

Critics also condemn the way newcomers are treated, insisting that immigrants are not necessarily required to learn the host country's language but then live in some ethnic enclave on government subsidies, and thus on the taxes of their hosts (Weigel, 2018).

But it is very important to understand that this criticism has quite symbolic form, which often turns into populism, and is used as a tool in the hands of right-wing parties. For example, subsidies only apply to those who seek refugee status in Europe, and are bestowed by governments, and strictly in accordance with the law. The sums are only enough to buy food with, thus this money is spent within the country which gives it, hence not inflicting any damage to its economy.

With regard to criticism of giving minorities the opportunity to express their distinct identities and practices, we need to understand that this pertains to the so-called celebratory model of multiculturalism, which encourages citizens' ethnocultural diversity: it provides support for the different traditions, customs, music and cuisine which exist in a multiethnic society (Kymlicka, 2012). Here nationalism is to be explained as the issue of nation is usually a core subject in criticism of multiculturalism. However the sense of nationalism's theory only proofs its inalienability from multiethnic basis. It is important to consider nations as a product of nationalism thus of a nationbuilding process. Explanation of a nation's concept is not an easy task, but several key moments connected with multiculturalism could be mentioned. For example B. Anderson (and many others) claim that a nation is an imagined political community because members of it will never know, hear or meet most of their fellow-members. They may be very different from each other and even understand and see their «common» nation from a different perspective, but have an imagined sense of community and solidarity. Thus, a term «imagined» gives as permission to consider the concept as a matter of subjective thought.

While there are no strict rules and standards distinguishing people on who pertain to a particular nation and who don't, most nations are limited and do not allow everybody to join it that sometimes makes necessity and role of a nation even more debatable in the modern realm, and the tendency towards rejection of nation's concept is clearly seen, particularly in states with leanings in favor of multiculturalism, justly considering it to be an essential part of any modern state. 
Worth to mention that many intellectuals, consider the idea of a nation to be a narrative of specific kind. Its actualization of separate themes has a situational character. «The targets of national narratives are the heart of humans and not the minds» (Chkhartishvili, 2013) Thus, bearing these characteristics in mind we can assert that what understood as a nation is blurred enough and ideas on multiculturalism's threat for a nation are quite ambiguous.

Back to the issue if minorities' desire to manifest their distinct identities and practices, here to be mention that in a democratic society it should not be a matter of anxiety as judicial authorities serve as a guarantor that any wild and inappropriate rituals newcomers might practice are strictly regulated and treated as criminal acts. For example, female circumcision and forced marriage are crimes in all civilized countries.

The celebratory features of multiculturalism serve as an engine of innovation and development for societies. Even though the superficiality of so-called celebratory multiculturalism is often criticized due to its lack of usefulness in addressing real social and economic challenges, this is due to the wrong implementation of multicultural policies rather than multiculturalism itself.

Many wrongly accuse multiculturalism of direct support for homosexuality through the protection of minorities' rights. However, people often forget that in a democracy none of the resolutions concern is accepted by governments without the support of the majority of the population. The most germane example in this regard is referendum that was passed in Ireland in 2015 concerning same sex marriage (The Irish Times, 2015). Therefore, the right to vote and fair elections, as well as referendums, deserves to be given much more attention. Moreover, monitoring in such cases is to depict the actual position of citizens.

All described above covers only the most frequent criticism of cultural pluralism and shows that it does not stand up to scrutiny. In addition, to strengthen multiculturalism's position, it would be useful to pay more attention to advantages that multiculturalism brings, and back to its historical role, to accept cultural pluralism as inevitability of any nation.

From analyzing general multiculturalism's criticism, we are moving to its condemnation in Georgia within the context of the far-right march which was first held in Tbilisi in the summer of 2017. This was the first such event in the country's modern history, and it served as a stage for claims by the radical right party "Georgian March" and voiced threats that immigration brings harm to Georgia. Several main slogans of the march were "We'll clear our streets of foreign criminals!", "What is Georgian is for Georgia alone", "Go back where you belong!". As one of leaders of the above mentioned party Sandro Bregadze said: "the idea of the march is not new, but the decision to hold it was accelerated by the increased criminal cases by immigrants in Georgia (Expressnews, 2019)". After that the march had been held several times by the mid 2019 and in all cases messages to the public had ultra-right character. Even though activists' actions are not illegal, emphasis is still placed on foreigner's criminal actions, thus emphasizing ethnical and cultural background of offenders. There were some cases connected with desecration of Churches, harassment, physical violence by immigrants from Middle East, etc. Even though these cases are particular, rightists use this information to play on the emotions of citizens; they were able to get more and more public attention. Disinformation and gutter press, as for example «Asaval-dasavali», contribute to the rise of right sentiments in the country. In 2018 there was an article by Nikoloz Mjavanadze devoted to the «problem» of reportedly huge flow of Iranian citizens to Georgia during the last several years. Allegedly, $70 \%$ of all sold apartments are purchased by Iranian citizens and in the nearest future there will be Iranian, Turkish, Arabic and African neighborhoods in Tbilisi where Georgians are not going to be welcome. For sure, thanks to official statistics we can dispel it, however some parts of citizens tend to rely on such tabloids and are easily misled (Mythdetector, 2019 ).

The issue of LGBT rights in Georgia is also in the spotlight of rightists, especially as it causes a strong public outcry and helps to highlight ideas of the right-wing parties intertwining issues of migration and tolerance. They actively use it to pay attention to their movement. The recent events can be used as the example in this case: members of «Georgian march» together with a businessman of ultraconservative views and businessman Levan Vasadze, held a rally against the premiere of the 2019 Swedish-Georgian drama film - And Then We Danced scheduled for November. The protesters claim there is no place for propaganda of homosexuality in Georgia, while stating that people of a different sexual orientation can feel absolutely secure in the country and no any discrimination exists against them.

In 2016 Bregadze was running for parliamentary elections with an open campaign against immigrants and gays in Georgia. Although the attempt was unsuccessful, every year the party's supporters' increase in numbers. The appetite for far-right ideas has dramatically increased in the period from 2015 to mid-2018 according to the research by Crrc-caucasus.blogspot.com. (2019). It is worth mentioning that the right-wing ideas are also represented in the Parliament by traditional-values party "Patriot's Alliance" having five seats. The party is a brilliant example of contemporary European illiberal populist movements supporting "protectionist measures and is particularly generous on welfare spending. The party pledges to decrease the state pension age and provide free housing, healthcare services, food, clothing, transport and medications to the socially vulnerable. It also promises to establish a statesponsored fund for providing non-interest loans and property, as well as the state-funded lawyers, accountants and managers to start-up businesses ". However, such populist claims easily find support from population in young democracies.

Attitudes that exist among right movements in Georgia are first of all against immigration and draw their policy upon traditional values and religiosity criticizing multiculturalism and interpreting it as a threat for Georgian culture and at the same time undermine democracy claiming to prohibit foreign NGOs in Georgia accusing them into waging war on Georgian culture (Nikoladze, 2019). 
It appears to be quite dangerous according to the difficult macro-economic situation in Georgia. Taking into account the fact that far-right sentiments easily grow during economic crises (Foreign, 2019) we may be absolutely sure that the complicated situation in Georgia with touristic sector (after banning flights from Russia) resulting into economic crisis, currency devaluation (RadioFreeEurope/RadioLiberty., 2019) will only play into the hands for radical attitudes among citizens. Particularly vulnerable part is unemployed $12.7 \%$ population being a target audience of rightist (Geostat, 2019).

\section{Role and Importance of Multiculturalism for Georgia}

It would be difficult to underestimate the role and importance of multiculturalism, particularly knowing the composition and history of Georgians. Multiculturalism is not even a choice for Georgia but rather is a historical reality. The fact that people identify themselves as Georgians at the same moment possess tradition, cultures and languages different from each other should be a key and basis for creation of a new multicultural approach for newcomers. For example, Svans, Megrelians and Kakhetians speak three different languages where one is common, and have different traditions and customs. Even though languages pertain to one group, it would be impossible for a Svan to understand Megrelian and vice versa.

Their cultures, even being united by the same religion, still have significant difference. For example, funeral traditions, religious customs or pagan beliefs. However, today the borders between ethnic groups of Georgians become more blurred due to progress: better road, communication and mass media, thus only increasing the consolidation of the people. Thanks to the fact that all ethnic groups identify themselves as Georgians we do not have separatism tendencies in these cases. For example, ethnic group of Adjarians, being part of Turkish Empire for centuries and following Islam, are perceiving themselves as Georgians.

The totally different story is with those ethnicities in Georgia who, in spite of living on the same territory for centuries, do not consider themselves as Georgians, as for example Abkhazians, Ossetians, Azerbaijanis or Armenians. So, exactly correct multicultural approach would serve as a tool for dealing with such type of problems in order to avoid separatism issues and disintegration. We also need to recall the VI article of the Kars' agreement and mentioned there conditions under which Turkey agrees to cede to Georgia suzerainty over the town and port of Batumi: "the population of the localities... shall enjoy a greater measure of local administrative autonomy, that each community is guaranteed its cultural and religious rights, and that this population may introduce in the abovementioned places an agrarian system in conformity with its own wishes (Groong.usc.edu., 2019)". Hence, Georgia should be very careful with the issue of multiculturalism and population's cultures and religions otherwise it all may threaten country's integrity.

Dealing with this issue is going to be task for Georgia if it wants to pretend on being a successful state in the future and bring back currently occupied territories. However, it does not mean that all peoples living in the country, must consider themselves of Georgian ethnicity, but it is to create conditions where they understand their culture is secured and they are not afraid of losing their identity being part of Georgian society and having its citizenship, thus to help them feel undisputable and inherent part of the country. Hence, those problems existing with this issue must be solved urgently. The detailed information on existing problems provided below.

\section{Multicultural Future}

Very few could accuse ethnic Georgians for lacking sufficient tolerance towards ethnical minorities or minorities in general. For example, a rich mosaic of religious groups in Georgia not only allows these groups exists side-by-side, but provokes mutual exchange of traditions, thus enriching and complementing each other. This feature of religious tolerance of Georgians, was noted by many and one of them was the French traveler Jean Chardin back to the second half of 17 th century he wrote: «...The liberty that everyone enjoys in Georgia, of living according to his own religion and customs, and of freely defending them (Chardin, 1815).' These words are relevant even now, proof is that after having two military conflicts within 17 years and being in constant tense with Russia no any cases of ethnic Russians, Ossetian or Abkhaz rights have been violated on a national basis. Or today while having $20 \%$ of the country occupied, Georgians have never intended to harass ethnic Russians. What could be better example of multicultural and tolerant nature of Georgian people?

The situation with ethnical composition is analogous. While Georgians account for the vast majority of the (86.8 per cent) of population (occupied territories excluded) the second and third places belong to Azerbaijanis and Armenians with 6.3 and 4.5 per cent, respectively. The other 2.5 per cent are divided between Russian, Ossetians, Yezidi, Ukrainians and Kists (Census, 2016). The numbers would definitely look differently, if not the occupation of 20 per cent of the country, and would support multinational situation of the country with more Abkhazian and Ossetian ethnic minorities in it.

It is worth noting that similarly to religious minorities, ethnic groups live side-by-side, complementing and enriching each other, thus creating specific and unique model of a Georgian populace, where the word Georgian is understood as a model of citizenship and equally pertains to all those living in Georgia. Although the hatred towards ethnic minorities in everyday life is not mentioned, we still have to recognize that there are plenty of problems on the official level.

If we have a deeper look into the issue we see there are enough problems with rights of ethnic minorities in Georgia, that strongly undermine its democracy. For example, the fact that in the regions with major non-Georgian population the language barrier exists. In Kvemo-kartli region people who are not fluent in Georgian language account for 38,5\%, approximately half of them do not speak Georgian at all. In Samtskhe-Djavakheti the situation is 
not better, the indicator is on $36 \%$ (Census, 2019). This makes a serious problem for these people to participate in social life of the community. Moreover, lack of language knowledge arises problems as information isolation of these people and impossibility to maintain relations with local official institutes and their representatives, thus causing alienation.

It is worth mentioning that the physical absence of ballots in ethnic minorities languages during elections also strongly undermine democratic stability in the country and violate the voting rights of citizens, thus makes it impossible for many citizens to vote or increases probability of being manipulated.

Consequently, mistrust towards country's internal politics is growing among ethnic minorities. According to OSGF research, only $12.6 \%$ of ethnic minorities members rely on political parties. Research also demonstrates that in political reality of today's Georgia there are no political parties expressing interests of ethnic minorities (TV, 2019). Thus all this is very interdependent.

The Union of Democratic Meskhs indicates that only in the Akhalkalaki office branch assisted 139 beneficiaries. They were helped in filling out applications for governmental agencies, as they lacked Georgian language skills: especially reading and writing. According to the Georgian administrative law any document of foreign language must be translated into Georgian and notary certified to have official power. Thus, it creates additional problems and challenges for ethnic minorities connected with costs of translation and notary service and as a result is quite time consuming (Gdi, 2019).

The next problem connected with language is education. For example, in regions with major Azerbaijani population children are taught by Georgian teachers who do not speak Azeri language, thus such education seems to be of low quality. The situation is not much better in Armenian schools where the educational program is based on Armenian official educational program and uses their materials, books, but at the same time level of Georgian language teaching is inappropriate (JAM News, 2019), thus minorities can't obtain a qualified education in official language and learn it. Additional problems appear when youth can't obtain university education due to lack of Georgian language skills, they stay in their provinces without opportunities for career growth and integration.

All explained above are not isolated cases rather than today's reality of Georgia's internal policy and multicultural problems within it.

\section{Georgian Citizenship - Historical and Ideological Multiculturalism}

The unifying and integrating model of citizenship should be premise for «Georgia of future» where multiculturalism should be reevaluated, renewed and presented as an ideological framework for better integrating of newcomers from the near neighborhood as well as China, Africa, Middle East and India. Problems that exist with national minorities in Georgia must be resolved on the basis of new multicultural agenda. The priority should be given to Georgian language, however allowing minorities learn their own languages. Minorities should be actively informed about importance of learning Georgian language for career perspectives and their integration into the society.

Earmarking a day for manifestation of multiculturalism is must. Festival on that day of solidarity between different ethnicities and cultures should be celebrated where importance of roles of these peoples will be highlighted and every culture will be endowed with responsibility for Georgia's integrity and prosperity. Multiculturalism is to be involved in school program and where its role and importance must be explained. Exams of Georgian language and lectures of multiculturalism should be exposed to those who obtain citizenship without Georgian high school education.

The new model of citizenship itself should be a guarantee that people holding it respect and understand the importance of multi-ethnical composition of Georgia and tolerate different nations and cultures within the country and treat each other as Georgians first and only then as representatives of other cultures. Multiculturalism should be a part of country's strategy and ideology due to its importance for integrity.

New model of Georgian citizenship, is an embryo at this moment which cannot be left on its own, therefore closely monitoring is important. It is needed to be carefully considered otherwise, if ignored, it may have tragic consequences for the country's statehood and its integrity. Besides, this new model of citizenship, if properly designed may be very useful in the process of de-occupation of Abkhazia and Tskhinvali region.

Multiculturalism has always existed and remains an absolute inevitability of any modern society. The matter of its benefit and harm is absolutely dependent on the way it is handled. Thus the right approach towards multiculturalism in such situation is the key thing.

\section{Conclusion}

The paper has analyzed and determined the place and role of multiculturalism in Georgian society by exploring multiculturalism's historical context. It concludes that cultural diversity of the country always was and still remains as one of the main factors driving its development. The author concurs that impact of policy of cultural diversity is strongly depended on the way it is handled, thus to suggest that new approaches towards applications of multicultural policies are needed.

The changes in this regard could be unified and imposed on society under the idea of the new model of Georgian citizenship with new responsibilities and requirements in achieving it. However, this model is only partly described without going deeper into details allowing others to supplement the idea with suggestions or criticism. 


\section{References}

Barbashin, M. (2012). Soviet identity in ethno-social space: institutional features. [online] cyberleninka.ru.: Available: https://cyberleninka.ru/article/n/sovetskaya-identichnost-v-etnosotsialnom-prostranstveinstitutsionalnye-osobennosti

Census, G. (2016). Mosakhleobis 2014 tslis sakoveltao aghceris dziritadi shedegebi. Available: http://census.ge/files/results/Census\%20Release_GEO.pdf

Census, G. (2019). Census - demographiuli da sotsialuri makhasiateblebi. Available: http://census.ge/ge/results/census1/demo

Chardin, J. (1815). Travels of sir john chardin through mingrelia and georgia into persia. Dublin: J. Christie. 375.

Chkhartishvili, M. (2013). Georgian nationalism and the idea of georgian nation. Available: https://www.researchgate.net/publication/291882979_Georgian_Nationalism_and_the_Idea_of_Georgian_ Nation

Crrc-caucasus.blogspot.com. (2019). Georgia's far-right are anti-Russian but share Russian narratives. Available: http://crrc-caucasus.blogspot.com/2019/04/georgias-far-right-are-anti-russian-but.html

Expressnews, G. (2019). Chveni quchebi ucxo qveknebis kriminalebisgan gaitsmindeba“ - 14 ivlis «qartvelta marshi»- EPN.: Available: https://expressnews.com.ge/?id=48272

Foreign, A. (2019). The financial crisis is still empowering far-right populists. Available: https://www.foreignaffairs.com/articles/2018-09-13/financial-crisis-still-empowering-far-right-populists

Foreign Policy Research Institute (1999). Multiculturalism in world history - foreign policy research institute. Available: https://www.fpri.org/article/1999/09/multiculturalism-in-world-history/

Gdi, G. (2019). Available: https://www.gdi.ge/uploads/other/0/708.pdf

Georgian Kingdom of Kartli 302 BC-580 AD:

Geostat, G. (2019). Dasaqmeba da umushevroba - saqartvelos statistikis erovnuli samsakhuri. Available: https://www.geostat.ge/ka/modules/categories/38/dasakmeba-da-umushevroba

Groong.usc.edu. (2019). ANN/Groong -- Treaty of Berlin - 07/13/1878. [online] Available at: . Available: http://groong.usc.edu/treaties/kars.html

JAM News (2019). Saqartveloshi somkhuri skolebis 5 dziritadi problema. Available: https://jamnews.net/\%E1\%83\%A1\%E1\%83\%90\%E1\%83\%A5\%E1\%83\%90\%E1\%83\%A0\%E1\%83\%97\%E1\%83\%9 5\%E1\%83\%94\%E1\%83\%9A\%E1\%83\%9D\%E1\%83\%A8\%E1\%83\%98\%E1\%83\%A1\%E1\%83\%9D\%E1\%83\%9B\%E1\%83\%AE\%E1\%83\%A3\%E1\%83\%A0\%E1\%83\%98$\% \mathrm{E} 1 \% 83 \% \mathrm{~A} 1 \% \mathrm{E} 1 \% 83 \% 99 \% \mathrm{E} 1 \% 83 \% 9 \mathrm{D} /$ ?lang=ka

Japaridze, A., Saqartvelos, T. M. and Kivchagta, C. (2012). Available: http://www.nplg.gov.ge/gsdl//cgibin/library.exe?e=d-01000-00---off-0patriarc--00-1----0-10-0---0---0prompt-10---4-------0-11--11-ka-50--20-about---00-3-1-00-0-0-11-1-0utfZz-8-

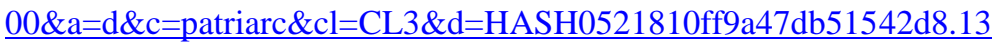

Kymlicka, W. (2012). Multiculturalism: success, failure and the future.

Mythdetector, G. (2019). Claims about Iranians allegedly buying 70\% of apartments in tbilisi are groundless | myth detector. Available: https://www.mythdetector.ge/en/myth/claims-about-iranians-allegedly-buying-70apartments-tbilisi-are-groundless

Nikoladze, T. (2019). The Georgian March against migrants and NATO. [online] JAMnews. Available: https://jamnews.net/the-georgian-march-against-migrants-and-nato/

RadioFreeEurope/RadioLiberty. (2019). Russia-georgia flight ban comes into force. Available: https://www.rferl.org/a/putin-ban-on-direct-russia-georgia-flights-comes-into-force/30042902.html

Solargeneral.org (n.d). The collection of the works of David Lane. Available: http://www.solargeneral.org/wpcontent/uploads/library/collection-of-works-of-david-lane.pdf

The Irish Times (2015). Ireland becomes first country to approve same-sex marriage by popular vote. [online]. Available: https://www.irishtimes.com/news/politics/ireland-becomes-first-country-to-approve-same-sexmarriage-by-popular-vote-1.2223646

Topchishvili, R. (2005). Ethnohistorical etudes. Tbilisi.

Topchishvili, R. (2019a). European values' relations with Georgian ones. [online] Georgie-europe2014.tsu.ge. Available: http://georgie-europe2014.tsu.ge/french_geo/EVROPULI-GIREBULEBEBI-DA-IDENTOBAgeo.pdf

Topchishvili, R. (2019b). European values' relations with Georgian ones. Available: http://georgieeurope2014.tsu.ge/french_geo/EVROPULI-GIREBULEBEBI-DA-IDENTOBA-geo.pdf

TV (2019). Kvlevis tanakhmad politikur partiebs etnikuri umtsiresobebis mkholod $12.6 \%$ endoba, arasamtavrobo organizaciebs ki 24.3\% - 1TV. Available: https://1tv.ge/news/kvlevis-tanakhmad-politikur-partiebsetnikuri-umciresobebis-mkholod-12-6-endoba-arasamtavrobo-organizaciebs-24-3/

VESPA (2016). Ideologicheskoe oruzhie globalizma. Multiculturalizm. Available: https://vesparevenge.ru/?p=1188

Weigel, G. (2018). Europe's two culture wars - commentary magazine. [online] commentary magazine. Available: https://www.commentarymagazine.com/articles/europes-two-culture-wars/ 